Mongolian Academy of Sciences
Mongolian Journal of Chemistry
Institute of Chemistry \& Chemical Technology

\title{
Study of rare earth elements in coal ash from Khartarvagatai coal deposit
}

\author{
B.Gantumur ${ }^{1}$, M.Pagmadulam ${ }^{1}$ \\ ${ }^{1}$ Hovd university, school of Natural Science and Technology, Department of Chemistry \\ baasandorjg@yahoo.com
}

\begin{abstract}
Have been investigated the mineral matter and chemical composition of ash from the Khartarvagatai coal deposite by X-ray fluorescence (XRF) and atomic absorption spectroscopy (AAS) methods. In the ash of this coal have revealed trace elements like Ce, Th, Be, La, Nd, Y, As. These elements come from mineral gasparite that present in raw coal. All diffraction patterns were analyzed by full-profile Rietveld refinements, using the software package WinPLOTR
\end{abstract}

Keywords: Khartarvagatai deposit, coal ash, rare earth elements, gasparite,

\section{Introduction}

oal serves as source of energy
resources and as source of organic
compounds of 21th century. Nowadays more than 90 percent of Mongolian power electricity and heat energy are produced by using of coal resources and coal is the main and reliable source of energy throughout in all aimags and soums of Mongolia.

Mongolia has a huge amount of coal resources and coal is cheaper in comparison with petroleum and natural gas. Demand of coal is increasing year by year. Unfortunately coal also may serve as source of pollutant of nature.

At the same time coal ash is reliable source of rare earth and dispersal elements. Recently coal deposits are beginning to evaluated by their contents of rare earth and dispersal elements because of their needs in modern industrial branches.

Therefore investigation of coal mineral matter, chemical composition and trace elements in ash is important task. Moreover, beneficiation of coal might give possibility to use coal completely without risk for nature damage.

\section{Experimental}

Coal samples from deposit Khartarvagatai located in western Mongolia were used in the study. Khartarvagatai coal deposit is located in Mongol Altai mountains region. According to coal area this deposit belongs to Kharhiraa coal basin.

The coal samples were ground and sieved to particle sizes $0.074 \mathrm{~mm}$ and subjected to

combustion in a muffle furnace at $600^{\circ} \mathrm{C}$ temperature to obtain ash samples. The contents of trace elements were determined by PANalytical AXIOS Advanced sequential X-ray spectrometer installed in Central geological laboratory of Mongolia. The glass disks are used for trace element determination are prepared by using mixtures of lithium tetraborate and lithium metaborate, Spectromelt A12, Merck. For the dilution $4200 \mathrm{mg}$ of this flux and 700 $\mathrm{mg}$ of the sample are weighed in platinumgold crucibles and fused for $15 \mathrm{~min}$ at $1100^{\circ} \mathrm{C}$. The melt is poured into pre-heated, polished $32 \mathrm{~mm}$-diameter moulds. For trace element determinations the standard deviations of consecutive analyses are in the 
range of 2 to $5 \%$ relative at the level of 20 to $30 \mathrm{ppm}$. Detection limits vary from 3 to $0.5 \mathrm{ppm}$ for the majority of the measured elements.

Phase analysis and determination of cell parameters at room temperature were carried out using X-ray powder diffraction (XPD) with Advanced D8 diffractometer (Cu$\mathrm{K}_{1}$-radiation) in transmission mode. All diffraction patterns were analyzed by fullprofile Rietveld refinements, using the software package WinPLOTR [1].

\section{Results and Discussion}

Mineral matter decreases the ability of heat releasing and has negative effect on coal processing. Therefore, it is important to determine content of the mineral matter and its chemical and mineralogical compositions of coal as well as ash.

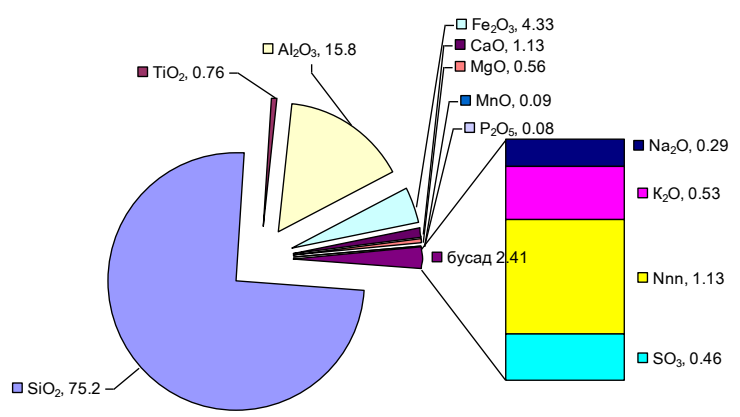

Figure 1. Chemical composition of coal ash in the Khartarvagatai coal deposit $(\%)$

As seen at figure 1 the content of silicon oxide and aluminum oxide prevailed otherwise the content of alkaline and alkaline earth metal's oxide are comparatively less. It is because of coal layer location of this deposit (1800 m below sea level) and consists of conglomerate, clay and quartz minerals [2].

Coal ash of Khartarvagatai deposit shows ratio $\left(\mathrm{Fe}_{2} \mathrm{O}_{3}+\mathrm{CaO}+\mathrm{MgO}+\mathrm{Na}_{2} \mathrm{O}+\mathrm{K}_{2} \mathrm{O}\right)$

$/\left(\mathrm{SiO}_{2}+\mathrm{Al}_{2} \mathrm{O}_{3}+\mathrm{Ti}_{2} \mathrm{O}\right)=0,079$, therefore has an acidic character [3]. Also $\mathrm{CaO}$ $+\mathrm{MgO}<\mathrm{Fe}_{2} \mathrm{O}_{3}$ an indication of bitumous character of this ash, and $\left(\mathrm{SiO}_{2}+\mathrm{Al}_{2} \mathrm{O}_{3}+\right.$ $\left.\mathrm{Fe}_{2} \mathrm{O}_{3}\right)$-sum is more than $70 \%$, therefore by ASTM C618 classification ash belongs to F class of ash [3].
X-ray difractogram of coal ash from Khartarvagatai deposit is shown at picture 2 and table 1.

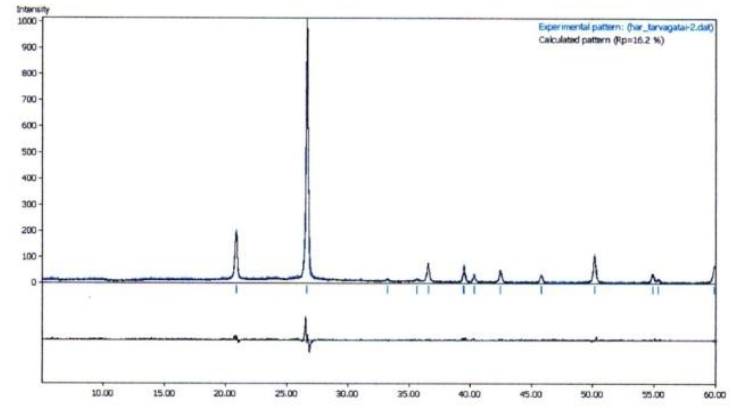

Figure 2. X-ray diffractogram of coal ash from Khartarvagatai coal deposit

At X-ray diffractogram of Khartarvagatai coal ash (picture 2, table 1) we saw $\mathrm{d}=4.25,3.34,2.45,2.27,2.12,1.97$, $1.81,1.67,1.54 \mathrm{~A}^{\mathrm{o}}$ quartz analytical line, $\mathrm{d}=1.65 \mathrm{~A}^{\mathrm{o}}$ muscovite line, $\mathrm{d}=2.69,2.51$, $1.90,1.79 \mathrm{~A}^{0}$ gasparite analytical line, consequently.

Table 1.X-ray parameters of the coal ash from Khartarvagatai deposit

\begin{tabular}{|c|c|c|c|c|}
\hline № & $\mathrm{d}, \mathrm{E}$ & $\begin{array}{l}\text { Name of } \\
\text { minerals }\end{array}$ & Chemical formula & $\begin{array}{c}\text { Symmetry of } \\
\text { crystal grid, } \\
\text { parameters of grid } \\
\text { (E) }\end{array}$ \\
\hline 1 & 4.25 & Quartz & $\alpha-\mathrm{SiO}_{2}$ & $\begin{array}{c}\text { trigonal, } \mathrm{P} 3_{1} 2_{1} \\
\mathrm{a}=4.9180, \\
\mathrm{c}=5.4070\end{array}$ \\
\hline 2 & 3.34 & & $\alpha-\mathrm{SiO}_{2}$ & \\
\hline 3 & 2.69 & Gasparite & $\begin{array}{c}(\mathrm{Ce}, \mathrm{Th}, \mathrm{Be}, \mathrm{La}, \mathrm{Y} \\
\mathrm{Nd})\left[\mathrm{As}_{0.71} \mathrm{P}_{0.29} \mathrm{O}_{4}\right]\end{array}$ & $\begin{array}{c}\text { betta-monoclin, } \\
\quad \mathrm{P} 2_{1} / \mathrm{n} \\
\mathrm{a}=6.9290 \\
\mathrm{~b}=7.1290 \\
\mathrm{c}=6.6970\end{array}$ \\
\hline 4 & 2.51 & & $\begin{array}{l}(\mathrm{Ce}, \mathrm{Th}, \mathrm{Be}, \mathrm{La}, \mathrm{Y}, \\
\mathrm{Nd})\left[\mathrm{As}_{0.71} \mathrm{P}_{0.29} \mathrm{O}_{4}\right]\end{array}$ & \\
\hline 5 & 2.45 & & $\alpha-\mathrm{SiO}_{2}$ & \\
\hline 6 & 2.27 & & $\alpha-\mathrm{SiO}_{2}$ & \\
\hline 7 & 2.12 & & $\alpha-\mathrm{SiO}_{2}$ & \\
\hline 8 & 1.97 & & $\alpha-\mathrm{SiO}_{2}$ & \\
\hline 9 & 1.90 & & $\begin{array}{l}\text { (Ce, Th, Be, La, Y, } \\
\text { Nd) }\left[\mathrm{As}_{0.71} \mathrm{P}_{0.29} \mathrm{O}_{4}\right]\end{array}$ & \\
\hline 10 & 1.81 & & $\alpha-\mathrm{SiO}_{2}$ & \\
\hline 11 & 1.79 & & $\begin{array}{c}\mathrm{Ce}, \mathrm{Th}, \mathrm{Be}, \mathrm{La}, \mathrm{Y}, \\
\mathrm{Nd})\left[\mathrm{As}_{0.71} \mathrm{P}_{0.29} \mathrm{O}_{4}\right] \\
\end{array}$ & \\
\hline 12 & 1.67 & & $\alpha-\mathrm{SiO}_{2}$ & \\
\hline 13 & 1.65 & & $\mathrm{KAl}\left[\mathrm{Si}_{3} \mathrm{AlO}_{10}\right](\mathrm{OH})_{2}$ & \\
\hline 14 & 1.54 & & $\alpha-\mathrm{SiO}_{2}$ & \\
\hline
\end{tabular}

The content of rare earth and dispersal elements in coal ash of Khartarvagatai deposit more than Clark of clay minerals, also the content of $\mathrm{Y}, \mathrm{Yb}$ more than the industrial content in coal ash. (table 2). 
Table 2. Average content of rare earth elements in coal ash from Khartarvagatai deposit (g/ton)

\begin{tabular}{|c|c|c|c|}
\hline $\begin{array}{c}\text { Earth } \\
\text { rare } \\
\text { elements }\end{array}$ & $\begin{array}{c}\mathrm{K}_{1} \text {-clark } \\
\text { in clay } \\
\text { minerals }\end{array}$ & Khartarvagatai & $\begin{array}{c}\text { Industrial } \\
\text { content* }\end{array}$ \\
\hline $\mathrm{Y}$ & 26 & $\mathbf{1 2 2}$ & 75 \\
\hline $\mathrm{Yb}$ & 2.2 & $\mathbf{8}$ & 7.5 \\
\hline $\mathrm{La}$ & 90 & 95.84 & 750 \\
\hline $\mathrm{Ce}$ & 50 & 174.8 & - \\
\hline $\mathrm{Nd}$ & 26 & 75 & - \\
\hline $\mathrm{Sm}$ & 4.5 & 29.47 & - \\
\hline $\mathrm{Pr}$ & 7.1 & 30 & - \\
\hline
\end{tabular}

*- Yudovich Ya.E. 1989

The results show that most of rare earth elements in the ash samples have contents lying in the ranges for most coals. The content of $\mathrm{Y}$ in coal ash of Khartarvagatai deposit was $122 \mathrm{~g} / \mathrm{t}$ (the highest content is $150 \mathrm{~g} / \mathrm{t}$, the lowest content is $94 \mathrm{~g} / \mathrm{t}$ ). It is known that the industrially applicable content of $\mathrm{Y}$ and $\mathrm{Yb}$ in coal ash are $75 \mathrm{~g} / \mathrm{t}$ and $7.5 \mathrm{~g} / \mathrm{t}$, consequently (Yudovich Ya. E.,1989). From above mentioned results we have made conclusion that the contents of $\mathrm{Y}$ and $\mathrm{Yb}$ in coal ash of Khartarvagatai deposit prevailed the industrial content $[5,6]$.

From figure 2, and table 1 we see that coal ash contain mineral gasparite which consist of following rare earth and dispersal elements like Ce, Th, Be, La, Nd, Y, As.

\section{Conclusions}

Ash from Khartarvagatai coal deposit contains quartz, muscovite and gasparite as mineral matters. Coal ash from this deposit belongs to acidic, bitumic, low calcium $\mathrm{F}$ class type coal ash by ASTM C618 classification. $\mathrm{Y}$ and $\mathrm{Yb}$ in Hartarvagatai coal ash have contents, allowing their industrial productions from coal ash. Khartarvagatai's coal ash contain mineral gasparite which consist of following rare earth and dispersal elements like $\mathrm{Ce}, \mathrm{Th}, \mathrm{Be}$, La, Nd, Y, As.

\section{References}

1. Bazarov.B.G at al., Journal og inorganic chemistry, 40 (1995) 13861388 (in Russ)

2. Bat-Erdene.D., Jargal.L. Coal basins of Mongolin Altai. Mongolian National University. UB. 1994.

3. Shpirt M.Ya. Utillization of mining's refuse and manufactured solid combustible natural resources. M.: Nedra, 1986. 256 p.

4. Sabkina M.A., Logvinenko A.T. Ash of subbitumus coal from KanskoAchinski. Novosibirsk: Sceince, 1979. $168 \mathrm{p}$.

5. Chemistry and technology of earth rare and dispersal elements: M.: high school., 1976. t. 2. 360 p.

6. Yudovich Ya.E. Gramm more than expensive ton: Earth rare elements in coal. M.: Science, 1989. 160 p. 